\title{
Cartucho, \\ de Nellie Campobello: la percepción dislocada de la Revolución mexicana
}

\author{
Begoña Pulido Herráez*
}

Resumen: El artículo estudia la poética narrativa de la obra Cartucho. Relatos de la lucha en el norte de México, de la escritora duranguense Nellie Campobello. Entre otros elementos se explora la forma de la voz narradora, fluctuante entre una voz infantil y otra que podemos ubicar como perteneciente a alguien adulto. Se concluye que la poética obedece a la forma de un álbum de fotografías de personajes anónimos de la Revolución mexicana; las imágenes enfocan en particular los momentos de la muerte.

Palabras Clave: Revolución mexicana, Cartucho, relato-historia, Nellie Campobello.

ABSTRACT: The article examines the poetic narrative of the novel Cartucho. Accounts of the fighting in northern Mexico, by the Durango writer Nellie Campobello. Among other things it explores how the narrative voice, fluctuating between a child's voice and one that we can place as belonging to one adult. We conclude that the poetry reflects the form of an album of photographs of anonymous people of the Mexican Revolution, the images focus on particular moments of death.

Key Word: Mexican Revolution, Cartucho, Nellie Campobello. 


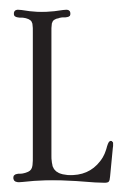

a biografía de Nellie Campobello Morton, nacida y bautizada como Francisca Luna Moya (Villa Ocampo, Durango 1900-Ciudad de México 1986), está llena de huecos, de lagunas y datos contradictorios ${ }^{1}$ que vienen a incidir en una obra hasta cierto punto poco conocida. Aun cuando en las últimas décadas haya ido creciendo en la consideración de la crítica, no por ello ha dejado de ocupar un lugar más bien periférico en el canon de obras y autores de la llamada Novela de la Revolución Mexicana, un espacio sin duda habitado por Mariano Azuela y Martín Luis Guzmán. Se necesitaría sin embargo, en aras de propiciar una historiografía literaria menos lineal, y asimismo menos centrada en los temas y más sensible a las formas artísticas, valorar la obra de la escritora duranguense y trazar la trayectoria que conduce a Juan Rulfo. ${ }^{2}$ Es difícil probarlo, pero creo que Rulfo leyó y abrevó en Nellie Campobello. Se habla de los silencios que pueblan la obra del jalisciense, de los rumores y de las voces del pueblo, de las resonancias de los tonos que reconocemos como pertenecientes a la oralidad peculiar del campesino mexicano, y no sería difícil encontrar esos mismos atributos (aun cuando trabajados de forma diferente) en la obra de Nellie Campobello. La suya es una escritura original, diferente, en el conjunto de lo que llamamos Novela de la Revolución Mexicana, una denominación ciertamente poco afortunada porque incluye en su seno obras que no son precisa-

1 Para todo lo relacionado con su biografía véase la investigación de Jesús Vargas Valdés y Flor García Rufino, Francisca Yo! El libro desconocido de Nellie Campobello, Chihuahua, Nueva Vizcaya Editores/Universidad Autónoma de Ciudad Juárez, 2004. Los autores argumentan cómo la propia Nellie se habría encargado de ocultar las huellas de algunos sucesos de su vida, por ejemplo cuando vivió en Ciudad Juárez trabajando como "adivinadora", o el hijo que habría tenido a los 19 años. También se refieren a la manía por alterar su fecha de nacimiento, 1909 en vez de 1900. Asimismo ubican el momento en que decide cambiar de nombre (y de identidad), abandonando el de Francisca por Nellie, muy poco tiempo antes de viajar a la Ciudad de México.

2 Dice Emmanuel Carballo en la introducción a la entrevista que aparece en Protagonistas de la literatura mexicana, México, SEP, 1986: "Nellie Campobello es, en la literatura mexicana contemporánea, una figura aislada. Lo peculiar de su sensibilidad y de su estilo la instalan en un sitio aparte. Su obra no entronca, visiblemente por lo menos, con nuestras más visibles corrientes narrativas; por otra parte, su obra no influye en las de los nuevos escritores. El único parecido que encuentro a sus libros es con su autora; y es tan grande que deja de serlo, se convierte en copia, en plagio. Plagian, principalmente dos de ellos: Cartucho y Las manos de Mamá, los acontecimientos significativos y triviales de la infancia de Nellie Campobello" (p. 409). 
mente novelas, y entre ellas se encuentra Cartucho. Relatos de la lucha en el norte de México.

La obra literaria de Nellie Campobello es relativamente breve, se compone de: Cartucho, publicada por primera vez en 1931 en una edición que contenía 33 breves relatos de difícil definición; Las manos de Mamá (1937), un texto dedicado a la memoria de quien sería siempre, a lo largo de su vida, una figura admirada por su valor y decisión, y Apuntes sobre la vida militar de Francisco Villa (1940), una obra donde, ayudada de documentos que le había proporcionado Austreberta Rentería, mujer de Francisco Villa, describe en un tono que no pretende ser literario sino en cierto sentido histórico, las campañas villistas que tuvieron lugar entre 1912 y 1918. ${ }^{3}$ Además de estos tres libros, Nellie Campobello publicó algunos poemas, un libro titulado Yo!, firmado con el nombre de Francisca y que el Dr. Atl editó en 1929, y Tres poemas (de Abra en la roca), de 1960. En ese mismo año salen a luz sus obras completas con el título de Mis libros, y recientemente, en el 2007, el Fondo de Cultura Económica imprimió la Obra reunida, donde incluye al final el interesante prólogo que la autora había escrito para la edición de 1960.

3 "Conviene aclarar que habiendo nacido yo en tiempo de la Revolución, no pude conocer al general don Francisco Villa y menos aún darme cuenta de su vida. Quien me habló de él por primera vez fue su viuda, la señora Austreberta Rentería de Villa. Ella me ha hecho conocerlo tanto en lo físico como en lo moral. Y me permitió leer el archivo de su difunto esposo, siendo allí donde me pude dar cuenta de las andanzas del guerrero. Durante una larga temporada asistí diariamente a la calle de Abraham González 31, aquí en México, y pude hacer apuntes. Hazañas de guerra en todos sus aspectos; su vida de soldado. Después hablé con algunos de sus dorados, José Nieto, Ismael Máynez, quienes me dieron todos los datos que les pedí. Por carta, otro dorado, Pedro Dávila, me dio información valiosísima. El distinguido y famoso escritor norteño señor Martín Luis Guzmán, quien ahora tiene parte del archivo, y fue villista, me ha aclarado y dado datos importantísimos para estos apuntes.

He ido a conocer varios lugares donde se dieron algunas de las batallas que se relatan aquí. Mi deseo era saberlo todo -imposible deseo-. Aquí sólo constan algunos de los hechos de armas de la vida de un guerrero; única que vivió Francisco Villa, conductor de hombres de guerra; en otro aspecto no existe. La verdad de sus batallas es la verdad de su vida." En la "Nota preliminar" de los Apuntes sobre la vida militar de Francisco Villa, tomado de Obra reunida, México, FCE, 2007 , p. 203. Se destaca el hecho de haber consultado los papeles de Villa y la búsqueda de testigos que completaran los datos y dieran fe de lo que cuenta. La investigación se pretende en cierta forma histórica. 
El aporte de Nellie Campobello a la llamada Novela de la Revolución Mexicana se debe a su obra Cartucho. Relatos de la lucha en el norte de México, publicada, como dije anteriormente, en 1931 en una primera versión que contenía 33 relatos y cuya edición fue auspiciada por el estridentista Germán List Arzubide, quien la incluyó en la editorial veracruzana Ediciones Integrales. Los Relatos de la lucha en el norte de México tuvieron una segunda edición en 1940, la que manejamos hoy en día, corregida y ampliada a 56 pequeños cuentos divididos en tres secciones (las mismas de la primera edición): 1. Hombres del Norte (que incluye siete breves historias que llevan el título de esos hombres cuyo instante ante la muerte se narra: "Él", o sea, Cartucho, el que da título al libro, "Elías", "El Kirilî", "El coronel Bustillos", "Bartolo de Santiago", "Agustín García" y "Las cintareadas de Antonio Silva"), 2. Fusilados (con 28 relatos), y 3. En el fuego (21 cuentos). No hay duda de que la corrección y la ampliación de los pequeños cuentos que Nellie Campobello fue acumulando durante años en su "libreta verde" se deben, en buena medida, a la relación estrecha, íntima, con Martín Luis Guzmán.

De julio a noviembre de 1929 las hermanas Nellie y Gloria Campobello permanecieron en La Habana. Allí conocieron al escritor José Antonio Fernández de Castro, quien hubo de ser hospitalizado a causa de un accidente. En sus visitas al hospital, Nellie Campobello comenzó a relatarle al cubano las historias revolucionarias que iba acumulando en su libreta verde.

Así fue como cada tarde le llevaba mis fusilados escritos en una libreta verde. Los leía yo, sintiendo mi cara hecha perfiles salvajes. Vivía, vivía, vivía [ ... ]. Acostaba a mis fusilados en su libreta verde. Parecían cuentos. No eran cuentos. Allá en el norte donde nosotras nacimos está la realidad florecida en la Segunda del Rayo. En el cerro de la Mesa, de la Cruz, de las Borregas, de la Iguana, y el gigante Cerro del Espía, allí donde han quedado frescas las pisadas y testereando entre las peñas las palabras de aquellos Hombres del norte. Mis fusilados, dormidos en la libreta verde. Mis hombres muertos. Mis juguetes de la infancia. ${ }^{4}$

4 Tomado de Blanca Rodríguez, Nellie Campobello, eros y violencia, México, unam, 1998, p. 79. 
Destaco de esta cita, además del hecho de que los relatos fueron naciendo como unidades independientes que se fueron sumando a lo largo de un tiempo que podemos suponer de al menos varios meses o incluso años, la imagen de la calle Segunda del Rayo y en general de la ciudad de Parral y sus cerros, como lugares donde han quedado impresas, frescas aún, las pisadas y las palabras de los revolucionarios del norte. Y en efecto, Cartucho está construido a partir de un lugar-centro de enunciación que es la casa de la Segunda del Rayo, a donde van a confluir los actos y las voces de los testigos y sobrevivientes de la lucha villista entre los años 1913 y 1918.

Tal y como expresa el propio subtítulo, se trata de una colección de 56 pequeños relatos, cuentos, "estampas" las han llamado otros críticos, cuyo origen espacial de enunciación se ubica en una casa situada en la calle Segunda del Rayo de la ciudad de Parral, Chihuahua, y cuya voz pertenece a una niña que aun cuando permanece anónima la mayor parte del tiempo, en el cuento titulado "Las rayadas" (incluido en la tercera parte, la titulada En el fuego) dice llamarse Nellie: "Allá en la calle Segunda, Severo me relata, entre risas, su tragedia:-Pues verás, Nellie, cómo por causa del general Villa me convertí en panadero". Esta atribución, más los datos perfectamente conocidos acerca de personajes históricos, o de la infancia y adolescencia de la autora en Chihuahua, la presencia de personajes familiares como sus hermanos El Siete y Gloriecita, pero sobre todo su Mamá (Ella, a menudo protagonista en los cuentos y de cuya boca escucha la narradora una parte importante de los relatos que a su vez nos transmite), dota de un valor testimonial a estos pequeños "balazos" (si los podemos llamar así, por su estilo breve, directo), cosidos por la voz de una niña. Cartucho se ubica en esa frontera siempre problemática entre la realidad y la ficción, o mejor entre la imaginación y la realidad. Y como sucede con frecuencia en estos relatos conflictivos, la dificultad, para nosotros lectores, de aprehender el mundo que nos propone la niña y de "compenetrarnos" con él, proviene de las peculiaridades de esa voz narradora y del modo particular en que rescata para la escritura las experiencias vividas, el modo en que aprehende y formaliza figurativa o imaginariamente sus relaciones con la realidad de la lucha revolucionaria. Efectivamente, la voz que cuenta "juega" con la Revolución, juega con los soldados que 
a diario pasan frente a la ventana de su casa de la Segunda del Rayo, juega con los muertos que quedan tirados durante días en la calle y que la niña se apropia y hace suyos, juega a proporcionarnos la información de múltiples y pequeñas historias, hechas de soldados anónimos para la Historia (con mayúsculas) pero íntimos, cercanos a la narradora, gente a veces sin nombre, otras con nombre y apellido pero casi siempre habitantes de eso que se llamó la "bola", siempre "hombres del Norte", como reza el título de la primera de tres partes en que se agrupan los relatos, cuya filiación, su origen en tal pueblo o tal otro de Durango o Chihuahua, junto con una breve descripción de los rasgos físicos más sobresalientes, son los datos que la narradora proporciona en cada historia: Bartolo es "Bartolo de Santiago" (de Santiago Papasquiaro, Durango), Elías Acosta "nació en el pueblo de Guerrero, del estado de Chihuahua", el coronel Bustillos "había nacido en San Pablo de Balleza", Antonio Silva "había nacido en San Antonio del Tule, allá por Balleza", Zafiro y Zequiel son dos indios mayos, "amigos" de la narradora, "indios de San Pablo de Balleza", José Antonio era de Villa Ocampo, Salvador es "de la calle Segunda del Rayo, nació allî", el general Tomás Urbina había nacido en Nieves, Durango. La de Nellie Campobello es la microhistoria de la Revolución mexicana por dos razones, por recoger la historia de los anónimos, del pueblo, y proporcionarles un nombre, una identidad, un ser, aunque sea por un tiempo efímero pues son los relatos que rodean y preceden a la muerte (a menudo al fusilamiento seguido siempre del tiro de gracia), y por tener su lugar de origen en una niña.

El primero de los relatos, titulado "Él" en la edición de 1940 y "Cartucho" en la de 1931, sienta las bases de la ética y la estética que van a regir el conjunto de la obra: la de la precariedad de vidas que se dirigen sin dudar y sin melodrama a su destino de muerte, y una precariedad también en el lenguaje, lleno de elipsis, silencios, huecos por donde se cuela la tragedia: "Unos días más. Él no vino; Mamá preguntó". Abundan las descripciones que son realmente enumeraciones, donde falta el verbo o los nexos predicativos. Estas descripciones sintéticas de los personajes inician con frecuencia los breves relatos, como sucede en "Elías" (el segundo de los cuentos): "Alto, color de canela, pelo castaño, ojos verdes, dos colmillos de oro - se los habían tirado en un combate cuando se estaba 
riendo-", 5 de tal modo que desde el principio se hace evidente la intención de relatar estas historias de la revolución construyendo imágenes, instantes congelados, fotografías que podrían asimilarse, en el plano de la escritura, a esas fotos en blanco y negro que nos han quedado como testimonios de las personas anónimas que participaron en las luchas revolucionarias. No se trata de un libro malogrado, como quiso parte de la crítica, porque estuviera mal escrito, sino que desde la primera historia se percibe la búsqueda de un lenguaje para contar algo sin precedentes, algo diferente. Otros dos elementos que se anuncian ya desde el comienzo y que tienen que ver con la poética particular de la obra son, por un lado, una perspectiva de las luchas desde un ángulo que no es propiamente político sino intimista, se narra desde la interioridad de una pequeña ciudad, un pueblo, una calle, una familia, cómo todos ellos se ven desquiciados, alterados y vueltos a enquiciar en una nueva forma de vida que incluye la muerte violenta; el otro elemento tiene que ver con el juego, ligado al hecho de que sea una niña la voz que nos cuenta; qué mejor forma de integrar, de naturalizar la muerte que mediante el juego. Elías "Cuando quería divertirse se ponía a hacer blanco en los sombreros de los hombres que pasaban por la calle. Nunca mató a nadie: era jugando y no se disgustaban con él" (p. 49). En "Él", o sea, Cartucho, y en esos pequeños cuentos que constituyen la primera parte, "Hombres del Norte", el lector se ve impelido a involucrarse de otra forma en la historia de la Revolución.

La voz narradora del relato, sea éste una colección de cuentos, una suma de estampas revolucionarias, un testimonio de la barbarie revolucionaria, una crónica familiar, o cualquier otra denominación que le podamos atribuir, ${ }^{6}$ la voz que

5 Otro ejemplo de descripción sintética puede encontrarse en "El coronel Bustillos", donde las frases cortas van yuxtapuestas, sin lazos de subordinación o coordinación: "Bustillos tenía unos bigotes güeros, tan largos que le sobresalían de la cara; siempre traía la punta derecha agarrada con los dedos; andaba lentamente; era blanco, con los ojos azules; su cara parecía la de un conejo escondido. Nunca se reía; sabía hablar mayo. No se vestía de militar; portaba sombrero tejano blanco y vestido azul marino, un cinto apretado de balas y su pistola puesta del lado izquierdo" (p. 51).

6 Véase el prólogo de Jorge Aguilar Mora a la edición de Nellie Campobello, Cartucho. Relatos de la lucha en el norte de México, México, Era, 2000: "Cartucho está justamente en todos esos vértices críticos de nuestro discurso histórico-literario: es quizá el libro más extraordinario 
nos cuenta con tono imperturbable y distanciado lo que "ve" a través de la ventana de la casa que habita en la calle Segunda del Rayo en Parral, Chihuahua, o lo que "escucha" de labios de adultos como su propia madre, y que nos transmite a nosotros lectores, esa voz que elabora pequeñas historias recogiendo lo mejor de los orígenes orales del cuento, es la de una niña que juega con muñecas, aunque muy probablemente esté cerca de la adolescencia. La voz es por tanto, en primera instancia, una voz muy peculiar, poco común en la narrativa hasta ese momento y ausente de la llamada Novela de la Revolución. Además, es una voz femenina. Niña y mujer, sujetos que de entrada no participan en la lucha armada y que socialmente ocupaban un lugar que los estudios culturales definirían como subalterno. La otra característica singular de esta voz es su capacidad para aunar en su testimonio los datos íntimos, propios de una mirada interna, con el testimonio de la muerte cruel y bárbara, por ello Jorge Aguilar Mora puede decir que en este texto se suman relato autobiográfico, crónica familiar, relación histórica y yo añadiría, testimonio. En esta amalgama de materiales y en su articulación en torno a una poética no convencional, que busca por otro lado huir de la linealidad o de la causalidad, descansa lo mejor de este texto. Dice la propia Nellie en una entrevista con Emmanuel Carballo: "Intento abrir los nudos vírgenes de la naturaleza, referirme a la entraña de las cosas, de las personas, ver con ojos limpios el espectáculo que me rodea. Me sobra imaginación de novelista: todo lo convierto en imágenes". 7 Y efectivamente los pequeños cuentos son recuerdos convertidos en imagen:

"Zafiro y Zequiel". Dos mayos amigos míos, indios de San Pablo de Balleza. No hablaban español y se hacían entender a señas. Eran blancos, con ojos azules, el pelo largo, grandes zapatones que daban la impresión de pesarles diez kilos. Todos los días pasaban frente a la casa, y yo los asustaba echándoles chorros de agua con una jeringa de ésas con que se cura a los caballos. Me daba risa ver cómo se les hacía el pelo cuando corrían. Los zapatos me parecían dos casas arrastradas torpemente.

donde se funden — sin solución de continuidad— la singularidad autobiográfica, el anonimato popular, la relación histórica, la transparencia literaria, la crónica familiar" (p. 15). En adelante las citas de Cartucho serán de esta edición e irán en el cuerpo del texto.

Dice Nellie Campobello en la entrevista con Emmanuel Carballo, op. cit., p. 415. 
// Una mañana fría fría, me dicen al salir de mi casa: "Oye, ya fusilaron a Zequiel y a su hermano; allá están tirados afuera del camposanto, ya no hay nadie en el cuartel." // No me saltó el corazón, ni me asusté, ni me dio curiosidad; por eso corrí. Los encontré uno al lado del otro. Zequiel boca abajo y su hermano mirando el cielo. Tenían los ojos abiertos, muy azules, empañados, parecía como si hubieran llorado. No les pude preguntar nada, les conté los balazos, volteé la cabeza de Zequiel, le limpié la tierra del lado derecho de su cara, me conmoví un poquito y me dije dentro de mi corazón tres y muchas veces: "Pobrecitos, pobrecitos". La sangre se había helado, la junté y se la metí en la bolsa de su saco azul de borlón. Eran como cristalitos rojos que ya no se volverían hilos calientes de sangre. // Les vi los zapatos, estaban polvosos; ya no me parecían casas; hoy eran unos cueros negros que no me podían decir nada de mis amigos. // Quebré la jeringa (p. 64).

La raíz del estilo de Nellie Campobello es el contraste, la distancia entre lo que se dice y cómo se dice, que provoca en el lector una gran inquietud, y un sistema de metaforización que se aleja decididamente del realismo y que lo emparenta con posiciones más arriesgadas, vanguardistas: ${ }^{8}$ en este caso la imagen de la sangre percibida como cristalitos rojos que ya no se volverían hilos calientes (otra podría ser la descripción de la sonrisa de "El kirilí", "una sonrisa fácil hecha ojal en su cara"). Asimismo los pequeños relatos suelen tener la estructura cerrada del cuento, son textos redondos. A menudo la frase que cierra, como en el ejemplo de los zapatos y la jeringa en "Zafiro y Zequiel", recoge un detalle mencionado al comienzo y que busca convertirse en la imagen-síntesis final que va a permanecer en el recuerdo del lector. Otro ejemplo de los muchos que podríamos poner se ubica en el relato que abre la segunda parte (Fusilados) y que se titula "Cuatro soldados sin 30-30".

8 La voz y el tono de Cartucho debieron resultar extraños y probablemente difíciles de asimilar para la crítica y el público lector, lo que puede explicar que durante décadas la obra de Nellie Campobello pasara más o menos inadvertida. Sin embargo, no hay que olvidar que fue Germán List Arzubide el editor, en 1931, de la obra. No podemos dejar de reparar en que se trata de uno de los estridentistas principales, y no sólo eso, es su cronista y el ensayista del grupo. Sin duda debe haber percibido la "modernidad" del lenguaje de Nellie Campobello. En el prólogo de la primera edición el estridentista destaca precisamente "su fuerza emotiva ante la muerte y su ausencia de ambiciones", es decir, su sencillez, que en mi opinión es sólo aparente. Otro vanguardista, podríamos decir, José Juan Tablada, reparó asimismo en el tono de Cartucho: "De 
Y pasaba todos los días, flaco, mal vestido, era un soldado. Se hizo mi amigo porque un día nuestras sonrisas fueron iguales. Le enseñé mis muñecas, él sonreía, había hambre en su risa, yo pensé que si le regalaba unas gorditas de harina haría muy bien. Al otro día, cuando él pasaba al cerro, le ofrecí las gordas; su cuerpo flaco sonrió y sus labios se elasticaron con un "yo me llamo Rafael, soy trompeta del cerro de La Iguana". Apretó la servilleta contra su estómago helado y se fue; parecía por detrás un espantapájaros; me dio risa y pensé que llevaba los pantalones de un muerto.// Hubo un combate de tres días en Parral; se combatía "mucho.//"Traen un muerto - dijeron-, el único que hubo en el cerro de La Iguana". "En una camilla de ramas de álamo pasó frente a mi casa; lo llevaban cuatro soldados. Me quedé sin voz, con los ojos abiertos, sufrí tanto, se lo llevaban, tenía unos balazos, vi su pantalón, hoy sí era el de un muerto" (p. 61).

En este caso se retoma la imagen del pantalón que lleva el soldado y que parece el de un muerto, para adelantarnos a nosotros lectores el fin: "hoy sí el de un muerto". Nellie Campobello fragmenta los cuerpos y elige partes que, metonímicamente, representan el todo del soldado y connotan muchas más cosas de las que dice abiertamente. Si los "labios pálidos se elasticaron", esos labios pálidos ayudan a construir (junto con la delgadez del personaje y su semejanza con un espantapájaros) la imagen de hambre y miseria que hay en el soldado, que también metonímicamente, refiere al hambre generalizado de la época revolucionaria; "él sonreía, había hambre en su risa". Todos los elementos apuntan a lo precario, a vidas que en cualquier momento se derrumban, a la muerte, siempre presente pero a la que se procura ver sin melodrama, más bien como el destino al que se dirigen, voluntariamente, cada uno de los soldados villistas.

Todo relato "imagina", es decir, elabora y reelabora imágenes de los sujetos sociales y propone una relación particular con el mundo que constituye el relato,

Nellie Campobello [... ] acabo de leer el reciente libro - bárbaro, a pesar de sus delicadezas; rudo, no obstante sus conmovedoras melodías; dislocado, magüer su armonía esencial-. Pero bien hayan los libros rudos, bárbaros y dislocados, hoy que suelen producirse otros pretenciosos e inánimes [...] A veces parece que [la autora] ahoga sollozos, otras que ora, que grita con voz ronca $[. .$.$] De allí su redolencia selvática y esos broncos acentos líricos de ábrego en$ los resinosos pinares norteños. Y de allí también su pristinidad emotiva [ . . ] y ese feliz impresionismo con que, breve y justa, logra expresar y pintar". 
sea éste ficcional o testimonial. En el caso de Cartucho los cuentos que Campobello va cosiendo uno al lado del otro, o si utilizamos la imagen que proporciona el título a la obra, los cartuchos que va colocando uno tras otro como en una cartuchera villista, en una imagen que a todos nos viene a la cabeza cuando pensamos en la Revolución o cuando recordamos fotos de Francisco Villa, están enhebrados por la percepción del mundo propia del juego. La niña juega con sus muñecas, especialmente con una llamada Pitaflorida, y juega con sus soldados, con los cuales conversa desde la ventana de su casa. Los cuentos son siempre cuentos de muerte o, como dice el título de la segunda parte de Cartucho, que suma 28 relatos, cuentos de fusilados. Todos son personajes con los que la niña ha tenido contacto, los ha visto y ha hablado con ellos, si son villistas, han entrado a su casa y han conversado con su madre o han entrado con violencia buscando robarse a una prima o simplemente buscando armas, si son carrancistas, pues la madre de la niña es declaradamente villista. Los soldados, los "cartuchos" son, como sus juguetes, algo personal, íntimo, cotidiano. La guerra y la muerte son "el pan de cada día", algo doméstico, algo que pasa por delante de la puerta y que no sólo pasa sino que entra a la casa, que de ese modo se convierte en el centro del que irradian todos los relatos: el mundo dentro y visto desde la Segunda del Rayo. Lo peculiar de Cartucho radica en la mirada, en el punto de vista que da cuenta y en el modo como lo hace, eludiendo premeditadamente cualquier posibilidad de linealidad o cronología sucesiva. La preocupación por cómo iba a contar y organizar sus relatos, la pregunta por la forma artística inquietaba a Nellie Campobello. Dice en el largo prólogo que elaboró en 1960 para la edición de sus obras reunidas, tituladas en ese entonces Mis libros: "Latente la inquietud de mi espíritu, amante de la verdad y de la justicia, humanamente hablando, me vi en la necesidad de escribir. [... B Busqué la forma de poder decir, pero para hacerlo necesitaba una voz, y fui hacia ella. Era la única que podía dar el tono, la única autorizada: era la voz de mi niñez. Usar de su aparente inconsciencia para exponer lo que supe era la necesidad de un decir sincero y directo"?

9 Nellie Campobello, "Prólogo a Mis libros (1960)", en Obra reunida, México, FCE, 2007, p. 339. 
Según el testimonio de la autora, la única voz que podía dar el tono del relato era la de la niñez, pues allí, bajo la aparente falta de conciencia se esconde la sinceridad y un hablar directo. Es vox pópuli que "los niños siempre dicen la verdad". Es decir que con la elección de una niña instaura un pacto de sinceridad, de verdad de aquello que se cuenta, sin necesidad de recurrir a una estilización realista. La otra cuestión ligada a este asunto es la del tono, que reside justamente en "jugar" con la ausencia de una conciencia adulta. Al provenir de una fuente que suponemos infantil, su tono pretende rescatar la ingenuidad y sencillez características de una voz que no es adulta todavía, no inmersa en el orden y la racionalidad propios de la edad adulta. Una voz que "parece" no comprender la "gravedad" de los acontecimientos de que es testigo. Los niños ven las cosas de otro modo, así que la enunciación no parte de una conciencia racional o crítica de las cosas "que ve", sino que, por el contrario, ve y cuenta aparentemente sin juzgar, sin interpretar, sin criticar, sin racionalizar. La crítica del proceso revolucionario no está en la mirada que cuenta sino que nos compete a nosotros lectores. El juicio es nuestro. Veamos un ejemplo de cuento, el titulado "Las tripas del general Sobarzo", uno de los pocos relatos que no se desarrollan en la calle o en la casa de la niña:

Como a las tres de la tarde, por la calle de San Francisco, estábamos en la piedra grande. Al bajar el callejón de la Pila de don Cirilo Reyes, vimos venir unos soldados con una bandeja en alto; pasaban junto a nosotras, iban platicando y riéndose. “¿Oigan, qué es eso tan bonito que llevan?” Desde arriba del callejón podíamos ver que dentro del lavamanos había algo color de rosa bastante bonito. Ellos sonrieron, bajaron la bandeja y nos mostraron aquello. "Son tripas", dijo el más joven clavando sus ojos sobre nosotras a ver si nos asustábamos; al oír, son tripas, nos pusimos junto de ellos y las vimos; estaban enrolladitas como si no tuvieran punta. "Tripitas, qué bonitas, ¿y de quién son?", dijimos con la curiosidad en el filo de los ojos. "De mi general Sobarzo - dijo el mismo soldado-, las llevamos a enterrar al camposanto." Se alejaron con el mismo pie todos, sin decir nada más. Le contamos a Mamá que habíamos visto las tripas de Sobarzo. Ella también las vio por el puente de fierro. ${ }^{10}$

${ }^{10}$ Nellie Campobello, Cartucho. Relatos de la lucha en el norte de México, México, Era, 2004, p. 85. En adelante las citas de la obra irán en el cuerpo del texto entre paréntesis. 
El breve relato termina sin embargo (en mi opinión de forma fallida) con un añadido en la segunda edición, un párrafo final explicativo que rompe con la estructura del cuento y donde aflora la voz de la autora adulta: "No recuerdo si fueron cinco días los que estuvieron 'agarrados', pero los villistas en aquella ocasión no pudieron tomar la plaza. Creo que el Jefe de las Armas se llamaba Luis Manuel Sobarzo y que lo mataron por el cerro de La Cruz o por la estación. Él era de Sonora, lo embalsamaron y lo echaron en un tren; sus tripas se quedaron en Parral" (p. 85). La fluctuación de la voz narradora entre los dos momentos históricos, el de la lucha y la resistencia villista por un lado, y el de los periodos obregonista y callista por otro, tiene su equivalente en un uso oscilante de tiempos verbales: el presente para la fotografía, la imagen congelada de la infancia, y el pasado para el recuerdo y la crítica desencantada desde el presente cercano a la década de los treinta. La recuperación de "escenas" olvidadas de la historia revolucionaria, la de los perdedores, resulta más vívida si se cuenta como siendo presente.

La niña que narra se va convirtiendo, con el paso de los días, en una "experta en asuntos de muertos" (según dice ella misma). Cuando su amigo Babis (quien vende dulces en una vidriera de una tienda japonesa) le dice que quiere irse a la Revolución, ella muy en serio le replica: "Pero te van a matar. Yo sé que te van a matar. Tu cara lo dice" (p. 74). O al ver un hombre a caballo puede diagnosticar: "Va blanco por el ansia de la muerte - dije yo convencida de mis conocimientos en asuntos de muertos", por ello, "A pesar de todo aquel fusilado no era un vivo, el hombre mocho que pasó frente a la casa ya estaba muerto" (pp. 76 y 77). Las balas que pasan por la mera puerta le parecen bonitas, y frente a los trescientos hombres fusilados en el mesón del Águila, "es mucho muy impresionante, decían las gentes, pero nuestros ojos infantiles lo encontraron bastante natural" (p. 81). A la niña le parece maravilloso ver tanto soldado por las calles: "Hombres a caballo con muchas cartucheras, rifles, ametralladoras; todos buscando la misma cosa: comida" (p. 71). Su espíritu infantil vuela "para encontrar imágenes de muertos, de fusilados; me gustaba oír aquellas narraciones de tragedia, me parecía verlo y oírlo todo. Necesitaba tener en mi alma de niña aquellos cuadros llenos de terror, lo único que sentía era que hacían que los ojos de Mamá, al contarlo, lloraran" (p. 91). En este último ejemplo la voz viaja de nuevo al presente de la escritura. 
Asoma en los cuentos en ocasiones un desfase o una fluctuación entre dos voces. A veces, como en el ejemplo de "Las tripas del general Sobarzo" (las menos, afortunadamente, otro ejemplo sería el cuento titulado "Nacha Ceniceros"), se trata de un añadido explicativo, de modo que se yuxtaponen dos perspectivas que corresponden a dos edades y dos lugares de enunciación diferentes. Pero en otras, aun cuando es el tono "aparente" de la niña, en realidad su conciencia es demasiado lúcida. En ese aparente no decir, dice demasiadas cosas "casi imposibles" en una niña. Es decir que en la misma voz coinciden dos perspectivas, la de la narradora de 30 años que escribe su relato en la Ciudad de México una década después de haber vivido los hechos que relata, y la de la narradora niña, que es, finalmente, el personaje que proporciona unidad al relato. La narración suma las dos percepciones, la de una mujer ya adulta y la de una niña, aunque se asuma como perteneciente a esta última. En mi opinión es lo mismo que sucede en los cuentos de Rulfo, donde tenemos la sensación de asistir a un hablar campesino, parece que "escuchamos", "oímos" de forma directa el hablar subalterno, pero finalmente se trata de un lenguaje muy elaborado y letrado, podríamos decir. En el caso de Cartucho sucede algo similar: parece que escuchamos la voz de una niña y sin embargo es un tono profundamente trabajado, buscado, y bajo el cual se percibe al narrador adulto. El lugar de la enunciación desde la Ciudad de México ya pasados varios años de los sucesos se hace evidente en el cuento "El general Rueda": "Un día aquí, en México, vi una fotografía en un periódico" (p. 84), y especialmente en "Nacha Ceniceros". Aquí el añadido que se hace para la segunda edición expresa abiertamente el coraje hacia los que ganaron la Revolución. La versión conserva el viejo relato, el de 1931, que termina con el garabato del cuerpo que "Hacía una bella figura, imborrable para todos los que vieron el fusilamiento. Hoy existe un hormiguero en donde dicen que está enterrada". Separado por un discreto espacio en blanco, la segunda parte inicia: "Ésta fue la versión que durante mucho tiempo prevaleció en aquellas regiones del Norte. La verdad se vino a saber años después. Nacha Ceniceros vivía. Había vuelto a su casa de Catarinas, seguramente desengañada de la actitud de los pocos que pretendieron repartirse los triunfos de la mayoría" (p. 66). 
La narradora nos ofrece un testimonio diferente de la Revolución, precisamente de los hechos "borrados" de la historia de la Revolución, como dice en el cuento-homenaje a García Lorca "Las cinco de la tarde": "A los muchachos Portillo los llevó al panteón Luis Herrera, una tarde tranquila, borrada en la historia de la revolución; eran las cinco" (p. 68). Es testimonio porque, finalmente, lo que se nos cuenta es lo que la niña vio o escuchó de voces adultas. "Le contaron a Mamá", o "Cuentan", o "dijeron" son expresiones que abundan. En el texto titulado "Las lágrimas del general Villa", el testigo directo fue el tío: "Lo vio mi tío; él se lo contó a Mamá y lo cuenta cada vez que quiere" (p. 136). En el caso de "Las rayadas", Severo le relata, entre risas, "su tragedia". En "La voz del general" Severo, también testigo, le cuenta a la narradora: "Fue en San Alberto, junto a Parral", y "Así dijo Severo, reteniendo en sus oídos la voz del general Villa" (p. 135).

La fuente de información más importante es sin duda la de Mamá. Un relato como "Los hombres de Urbina", de la segunda parte, Fusilados, está estructurado precisamente con lo que contó o decía Mamá: "Le contaron a Mamá todo lo que había pasado. Ella no lo olvidaba. Aquellos hombres habían sido sus paisanos." Y enseguida: "Fue en Nieves - dijo Mamá_", "Llegaron las tropas a Parral - decía Mamá que todo fue tan espantoso, andaban tan enojados, las caras las tenían desencajadas de coraje-", "Muchos fueron los fusilamientos, todos eran mis paisanos — decía Mamá con su voz triste y sus ojos llenos de pena_-" "La voz de Mamá temblaba al decir que aquel hombre, soldado de la revolución, era nativo de su tierra", "Muchas fueron las cosas que le sucedieron a aquel hombre - decía Mamá con el recuerdo entre sus labios_", "Les mandé unos libros, tres libros - dijo Mamá, muy interesada en contar la tragedia de aquel hombre va-

${ }^{11}$ Dice Carballo: "La literatura de Nellie Campobello (verso y prosa) está hecha con la sustancia de su propia vida. Sus libros resultan insólitos (en sí mismos y comparados con los que se escribieron entre los años de 1931 y 1937) porque insólita es la vida en que están inspirados. Literatura de confesión, trascienden ese estrecho y estéril casillero. Sus textos son algo más; se convierten en el testimonio conmovido de una niña que no sólo ve hacia adentro de sí misma sino hacia donde se encuentran los demás: los hombres y mujeres que la rodean en su casa y en la calle. Literatura de la Revolución y revolucionaria. De la Revolución, porque describe con simpatía los hechos que ocurren en un mundo que va de la dictadura a la democracia; revolucionaria, porque desecha los esquemas técnicos de uso corriente e, intuitivamente, los reemplaza por otros más acordes a su propio temperamento." En Carballo, op. cit., p. 377. 
liente", "Dios guarde la hora - decía Mamá llena de dolor. Ningún fusilamiento estaba tan presente en su memoria como éste". Éstos son algunos de los muchos ejemplos que pueden encontrarse en las páginas de este relato. Los recuerdos y la voz de la madre funcionan como la corriente transmisora de la tragedia y el dolor. Si la voz infantil no lo puede percibir como tal, ya que su modo de aprehender la realidad está más cercano a las estructuras del juego y no a las de la tragedia, la voz adulta quizá tampoco puede, ya que inclinaría la balanza hacia las calificaciones ideológicas o morales. Mamá es como el álter ego de la narradora adulta, pero con la perspectiva y el grado de proximidad a los acontecimientos de los años de la infancia; por medio de ella puede decir otras cosas, es otra forma de percepción.

En la tercera parte de Cartucho aumenta la presencia de Francisco Villa. En las dos anteriores los hombres y mujeres que llenan los relatos son los villistas, soldados muchas veces, otras coroneles o generales pero protagonizando o participando de hechos que no son batallas, sino el encuentro de cada uno con la muerte en un acto que los define y les da vida. La muerte es, finalmente, lo que les da un lugar en los recuerdos de la narradora y lo que les da vida literaria. Cada relato es el epitafio que sella una a una las vidas de cada personaje, pero es también muerte para la vida. En Cartucho se proporciona un lugar en la "historia de la Revolución", como sucede con la muerte de los hermanos Portillo. En esta tercera parte en cambio, como decía, hay varios relatos que se refieren directamente a Villa y que lo incluyen como personaje, con voz propia, como en los mencionados "Las lágrimas del general Villa" o "La voz del general". De hecho es la voz la metonimia de Villa: "Metálica y desparramada. Sus gritos fuertes, claros, a veces parejos y vibrantes. Su voz se podía oír a gran distancia, sus pulmones parecían de acero". Los gritos que usa en los combates son "vibrantes, claros, que estremecían", es una voz que sabe atraerse a los hombres. "Dice Severo que aquel hervidero de gente, al oír la voz de su jefe, se paró como un solo hombre, dejando todo abandonado [...]. 'Los villistas eran un solo hombre. La voz de Villa sabía unir a los pueblos. Un solo grito era bastante para formar su caballería.' Así dijo Severo, reteniendo en sus oídos la voz del general Villa" (p. 134). En algunos de los cuentos la presencia de Villa se reconoce por la voz, como sucede 
en "Las rayadas”: “¿Qui-húbole muchachos, aquí es panadería?' Nosotros le contestamos el saludo y le conocimos la voz, al abrir la hoja de la puerta, le dio un rayo de luz sobre la cara y vimos que efectivamente era el general Villa" (p. 132), y en "El sueño de El Siete": "Fue el único momento feliz de su vida, porque oyó la voz del general Villa. 'Me recompensó Dios - decía cerrando los ojos-, oí a Tata Pancho' (p. 116). A las voces de los numerosos personajes que cuentan a la niña lo que vieron o lo que escucharon, se une la de Villa. Las voces adquieren así, en Cartucho, una dimensión particular, pues la de la narradora se convierte en el lugar donde resuenan muchas otras, pero las ofrece como un solo rumor que da testimonio de ese periodo de derrota del villismo entre 1915 y comienzos de 1919. La Historia que rescata Nellie Campobello no es la de las grandes batallas sino la de las pequeñas historias, y la historia de los anónimos.

En cuentos como "La voz del general" o "Las lágrimas de Villa" emerge la defensa directa del villismo y del general, con lo cual la presencia de la perspectiva adulta en la narración se hace más evidente y con ello las intenciones de la obra, su deseo de mostrar otra cara del villismo en momentos en que la Revolución camino a la institucionalización lo quería considerar más un "bandido" que un militar revolucionario. Los "añadidos" que sufren algunos cuentos en la segunda edición tienden a hacer más evidente la estrategia de una narradora adulta oculta tras la niña y destacan las intenciones ideológicas. Quizá el ejemplo donde esto es más claro es en el cuento "Nacha Ceniceros", de la segunda parte, Fusilados, donde leemos: "La red de mentiras que contra el general Villa difundieron los simuladores, los grupos de la calumnia organizada, los creadores de la leyenda negra, irá cayendo como tendrán que caer las estatuas de bronce que se han levantado con los dineros avanzados.// Ahora digo, y lo digo con la voz del que ha podido destejer una mentira: iViva Nacha Ceniceros, coronela de la revolución!" (p. 67). No hay que olvidar que Nellie Campobello comparó a Francisco Villa con Gengis Kan ${ }^{12}$ y con Napoleón.

12 "Al acercarme a través de la historia a los hechos de armas de los grandes generales del mundo, encuentro situado a Francisco Villa como el único genio guerrero de su tiempo, uno de los más grandes de la historia; el mejor de América y después de Gengis Kan, el más grande guerrero que ha existido.", nota preliminar en Apuntes sobre la vida militar de Francisco Villa. 
Al considerar de nuevo que la voz de la niña que cuenta recoge en la suya muchos otros relatos, muchas otras voces "de los de abajo", "cuentos" en el sentido originario de la palabra, relatos cara a cara, que le narran, o que escucha, la de la narradora viene a ser, como decía, una voz recolectora de muchas otras voces y testimonios. Algunas tienen nombre: Mamá, hasta el punto de que los relatos de ella son "Cuentos para mí, que no olvidé. Mamá los tenía en su corazón” (p. 100), o su tío abuelo, que conoció a Tomás Urbina y narra su historia, "como si fuera un cuento" (p. 103), no sin que la narradora le enmiende la plana ("Tomaba sus tragos de aguardiente de uva, y se adormecía entrelazado en los cabellos negros de alguna señora [composición hecha a escondidas de mi tío]" (p. 103), o simplemente eche mano de la "imaginación" que supone toda acción narrativa: "Urbina, con la estrella en el sombrero, con sus venas gordas, palpitantes bajo la piel prieta, abriendo los ojos hasta hacer gimnasia, haría un resoplido de general ante aquellas noticias. (Todo esto es una suposición inocente, nacida hoy, acá donde las gentes ignoran al Santo Niño de Atocha y al general Tomás Urbina.)" (p. 104). Otros personajes que narran sus historias son las vecinas: Chonita, Pepita Chacón, o soldados sobrevivientes, testigos directos de los sucesos: Isaías Álvarez, Severo, Salvador Barreno, etc., o simplemente "un poeta del pueblo que me narró espontáneamente la muerte del general Martín López" (p. 153); pero las más de las veces, los cuentos reproducen la voz de los anónimos, los "cuentan" sin nombre y apellido. En "Las mujeres del Norte", el penúltimo de los textos, son las voces anónimas de "aquellas mujeres testigos de las tragedias", que siguen preguntando por cada uno de los soldados y que recuerdan el lugar y la forma de cada muerte: "-iY Gándara? ¿Y el Chino Ortiz? -Sí - contestan aquellas mujeres testigos de las tragedias-, sí, cómo no, allí donde está esa piedra le tumbaron el sombrero y lo fueron a matar hasta allá, frente a aquella casa" (p. 157).

Y aquí entroncamos, para finalizar, con otro de los aspectos fundamentales de Cartucho que está relacionado con su pretensión testimonial. Los cuentos que leemos son recuerdos, propios y ajenos pero asumidos por la voz autobiográfica de la narradora, de la lucha a muerte que se dio en Chihuahua entre vilistas y carrancistas tras las derrotas de la División del Norte. Los breves relatos, como en todo cuento, reactivan el pistón de la memoria y sabemos que la me- 
moria funciona por imágenes. Al unir testimonio, memoria e imaginación Cartucho nos ofrece una novedosa visión de la Revolución mexicana y muestra que el discurso narrativo revolucionario brinda caras diferentes al clasicismo o al realismo de los textos canónicos.

Si la mirada y la perspectiva son elementos esenciales en Cartucho, existe la tentación de buscar un equivalente visual para el modo de organización formal de la obra. Así, se ha dicho que la obra es un "mural" de la Revolución; sin embargo, la asociación con un fresco social o con un mural afiliaría la obra al realismo, y en mi opinión es el lugar de donde Cartucho pretende alejarse. Quizá la metáfora fotográfica resulte un mejor equivalente: momentos congelados, imágenes que conservan su sentido inquietante. En la obra hay un personaje, Martín López, que lleva consigo una "colección de tarjetas" de su hermano fusilado, Pablo López: "En todas las esquinas se ponía a besarlas, por eso lloraba y se emborrachaba. Martín López era general villista, tenía los ojos azules y el cuerpo flaco. Se metía en las cantinas, se iba por media calle, se detenía en las puertas, siempre con los retratos en la mano; adormecido de dolor recitaba una historia dorada de balas" (p. 110). Cartucho puede ser leído como una colección de fotografías, un álbum de fotos de la antiépica de la Revolución, o de la otra Revolución, la no triunfante. Antiépica y también tragedia. Se ha dicho que Los de abajo es el relato épico de la lucha. Si se tratara de buscar la presencia de géneros clásicos en la narrativa revolucionaria, en Cartucho asoma la presencia de la tragedia, no sólo es una palabra que se menciona con cierta frecuencia, también se siente en la asunción del destino trágico en cada uno de los soldados que sabe que va hacia la muerte y acepta su destino sin melodrama, con actitud heroica y a veces gustosa.

Finalizo este acercamiento a la poética de Cartucho con una mirada sobre el cuento titulado "Desde una ventana", que pone en acción todos los juegos de la cámara (los ojos de la niña) que primero observa la escena desde lo alto y luego describe meticulosamente cada detalle del escenario. No sería errado reconocer en este estilo las artes del dramaturgo y del coreógrafo: artes de la escenografía que Nellie Campobello absorbió en sus años de bailarina. Este texto es profundamente teatral; el párrafo del comienzo podría ser muy bien la aco- 
tación escénica que precede en el drama al diálogo entre los personajes, lo cual se hace más evidente con la ausencia de verbos o el uso del tiempo presente al comienzo, antes del inicio de "la acción". Es de destacar asimismo la "imagen" poética de la soledad: "la tierra se quedó dibujada y sola". Permanece solamente la huella, el dibujo del cuerpo que es memoria del muerto olvidado y sin nombre que la niña se había apropiado, como Cartucho se apropia de tantos muertos ya olvidados. No hace falta hablar explícitamente de los cadáveres que con frecuencia, sin duda, llenaban las calles de Parral, y de las prohibiciones para levantar y dar digno entierro al enemigo. Las crueldades, las tragedias, la vida descompuesta y dislocada se expresan de modo figurativo, mediante imágenes "que valen más que mil palabras":

Una ventana de dos metros de altura en una esquina. Dos niñas viendo abajo un grupo de diez hombres con las armas preparadas apuntando a un joven sin rasurar y mugroso, que arrodillado suplicaba desesperado, terriblemente enfermo se retorcía de terror, alargaba las manos hacia los soldados, se moría de miedo. El oficial, junto a ellos, va dando las señales con la espada; cuando la elevó como para picar el cielo, salieron de los treintas diez fogonazos que se incrustaron en su cuerpo hinchado de alcohol y cobardía. Un salto terrible al recibir los balazos, luego cayó manándole sangre por muchos agujeros. Sus manos se le quedaron pegadas en la boca. Allí estuvo tirado tres días, se lo llevaron una tarde, quién sabe quién.

Como estuvo tres noches tirado, yo ya me había acostumbrado a ver el garabato de su cuerpo, caído hacia su izquierda con las manos en la cara, durmiendo allí, junto de mí. Me parecía mío aquel muerto. Había momentos que, temerosa de que se lo hubieran llevado, me levantaba corriendo y me trepaba en la ventana, era mi obsesión en las noches, me gustaba verlo porque me parecía que tenía mucho miedo.

Un día, después de comer, me fui corriendo para contemplarlo desde la ventana; ya no estaba. El muerto tímido había sido robado por alguien, la tierra se quedó dibujada y sola. Me dormí aquel día soñando en que fusilarían otro y deseando que fuera junto a mi casa (p. 88).

Recibido: 10 de diciembre, 2010.

Aceptado: 26 de febrero, 2011. 


\section{BIBLIOGRAFÍA}

Campobello, Nellie, Cartucho. Relatos de la lucha en el norte de México, pról. de Jorge Aguilar Mora, México, Era, 2000. , Obra reunida, México, FCE, 2007. , Apuntes sobre la vida militar de Pancho Villa, en Obra reunida.

Carballo, Emmanuel, Protagonistas de la literatura mexicana, México, SEP, 1986.

MatThews, Irene, Nellie Campobello. La centaura del Norte, México, Cal y Arena, 1997.

Rodríguez, Blanca, Nellie Campobello: eros y violencia, México, unam, 1998.

VARGas Valdés, Jesús y Flor GarCía Rufino, Francisca Yo! El libro desconocido de Nellie Campobello, Chihuahua, Nueva Vizcaya Editores/Universidad Autónoma de Ciudad Juárez, 2004. 